\title{
Barriers to the Implementation of the Articles of Continuing Acts in the Law of Criminal Acts of Corruption in Indonesia
}

\author{
Farida Kaplele ${ }^{1, *}$, Sigid Suseno $^{2}$, Lies Sulistiani ${ }^{2}$ and Elis Rusmiati ${ }^{2}$ \\ ${ }^{1}$ Doctoral Program in Law Science, Universitas Padjadjaran, Indonesia \\ ${ }^{2}$ Lecturer of Faculty of Law, Universitas Padjadjaran, Indonesia
}

\begin{abstract}
The problem that will be discussed in this paper is the problem of obstacles to eradicating criminal acts of corruption regulated in the Corruption Crime Act in Indonesia, which in its implementation is often associated with the existence of norms in Article 64 Paragraph (1) of the Indonesian Criminal Code which regulates criminal acts. (voorgezette handling) corruption in Indonesia. To overcome this problem, a search for documents and literature studies was carried out, a study of laws and regulations, including decisions on corruption cases that had existed, then carried out a descriptive analysis to solve the problem. The study results show that the obstacles in the application of Article 64 of the Criminal Code are related to continuing acts of corruption in Indonesia. First, the difficulty of separating a criminal act as a single offense if it is carried out by state officials who handle the same problem and project every time. Day; Second, it is often interpreted that the will's decision is an act of corruption itself; Third, the determination of material actions (feit materieele); and Fourth, continuous action is not only seen as a rule relating to the issue of the imposition of crime and the weighting of criminal acts.
\end{abstract}

Keywords: Corruption, Crime, Eradication, Indonesia.

\section{INTRODUCTION}

Corruption is closely related to power as Lord Action argued that power tends to be corrupt, absolute power corrupts absolutely (Dalberg, J. 1907). Absolute power will grow to be evil if there is no transparency, supervision, and accountability as in the corruption formula of Robert Klitgaard that corruption occurs when there is a monopoly of power and authority minus guilt (Klitgaard, R 2005). In society, identical with all behavior that breaks the criminal law or including dimension such as "evil act" (Harlina, I. and Slamet Riyadi, B. 2020).

Corruption has become an international concern and crime, as the birth of an international forum showing the great attention of the world community to sin with the signing of the United Nation Convention Against Corruption (UNCAC) in Mexico on December 11,2003 . The serious attention of the international community apart from various international conventions was also shown through the Corruption Perceptions Index issued by Transparency International.

The impact of corruption, which is worrying and is accompanied by the spirit of reform in all areas of the nation and state, the Indonesian government has begun to carry out a movement to reform the legal instruments of corruption (law corruption reform). Law corruption reform was one of the big agendas of reform

*Address correspondence to this author at the Faculty of Law, Universitas Padjadjaran. Jalan Raya Jatinangor, Cikeruh, Jatinangor, Sumedang Regency, West Java, 45363; Indonesia; E-mail: faridakaplele23@gmail.com in 1998. The leading national policy began with the issuance of the People's Consultative Assembly Decree Number XI of 1998 concerning the Implementation of a State that is Clean and Free from Corruption, Collusion, and Nepotism which was later strengthened by publication and amendments. Laws and regulations related to corruption.

Apart from strengthening anti-corruption policies, massive repressive efforts through law enforcement measures were also carried out. In the reform era, there was the disclosure of corruption cases on a large scale, ranging from corruption in the government, parliament, judiciary, law enforcement, state-owned enterprises to corruption involving (private) business actors. However, the government's policy steps in eradicating corruption have not been satisfactory because according to Wawan Suyatmiko, a researcher of the 2018 Transparency International Indonesia Corruption Perception Index, Indonesia is in a score of 38 (thirty-eight) and is ranked 89 (eighty-nine) out of 180 (one hundred eight) twenty) countries surveyed ( Furqan, AC, and Din, M 2019). Of course, these results have not shown significant progress. This situation illustrates that high levels of corruption are also correlated with various factors, including factors of laws and regulations. The handling of corruption, which in its implementation is often associated with criminal law institutions committing illegal acts or continuing acts (voorgezette handeling), is undoubtedly an exciting thing to examine to understand the obstacles in its handling. 
The handling of corruption cases that apply Article 64 paragraph (1) of the Criminal Code is often the decision of the panel of judges to impose a reasonably low sentence on the defendant, and this shows that Article 64 paragraph (1) of the Criminal Code has limitations in terms of punishment of perpetrators of corruption in Indonesia. In contrast, the perpetrators are proven to have committed more than one act of sin. This can be seen in several corruption court decisions which impose criminal penalties only in the form of imprisonment for 1 (one) year to defendants who are proven to have committed corruption on an ongoing basis, including the following:

1. Corruption Court Decision at the Bandung Class IA District Court Number 43/Pid.Sus/TPK/2016/PN.Bdg dated September 7,2016 , the defendant Jajat Supriyatna who was legally and convincingly proven to have committed a criminal act of corruption together and continues;

2. The decision of the Corruption Court at the Class IA Semarang District Court Number 67/Pid.Sus/TPK/2016/PN.Smg dated October 31,2016 , the defendant Suwardi who was legally and convincingly proven to have committed a criminal act of corruption together and continues;

3. The decision of the Corruption Court at the Class IA Semarang District Court Number 66/Pid.Sus/TPK/2016/PN.Smg dated October 31, 2016 defendant Susuri who was legally and convincingly proven to have committed a criminal act of corruption jointly and continuously.

The low level of punishment given to defendants who commit corruption continuously is, of course, inversely proportional to the characteristics given to criminal acts of corruption, namely as an extraordinary crime (extraordinary crime).

\section{METHODS}

This study approach uses a normative system. Data collected and analyzed were sourced from court decisions. The data source is limited to 3 (three) case years. The court decision is then linked to Article 64 of the Indonesian Criminal Code as a rule of punishment in criminal law that adheres to the absorption system.

\section{RESULTS AND DISCUSSION}

\section{Application of Article 64 of The Criminal Code in the Eradication of Corruption in Indonesia}

Nonstop action, translated from the Dutch "voorgezette handeling" is mentioned in different translations by several criminal law experts. The connection with the continuing activity is seen as a matter of illegal imposition regulations (straftoemetingsregel), so Article 64 paragraph (1) of the Criminal Code is only a guideline for public prosecutors and judges to apply crimes against the principal offense, in this case, the criminal act of corruption.

Adhering to the teachings of continuing actions is closely related to the qualifications of an act as a material act (materiel feit). Pompe argues that material acts are physical acts only, so they are only for commission offenses and do not have to be sought in other forms of crimes (Lamintang, PAF 1997). However, this material act is not just a physical act but is also prohibited by statutory regulations (feitelijkshandelingen). However, Hamel reminded that feitelijkshandelingen should not be confused with eendaadsche Samuel's open or idealist discourse. Some of these acts are subject to criminal provisions resulting in different criminal acts between one act and the next.

The separate difficulty in continuing action was mentioned by Pompe, who once stated his pessimism that Article 64 paragraph (1) of the Criminal Code should be abolished because, fortunately, it is not balanced with the practical difficulties it causes (E. Utrecht 2001). The debate related to continuing actions can be understood because, according to P.A.F Lamintang, the teaching of the same loop is one of the most challenging teachings in the science of criminal law (Lamintang 1984). According to S.R Sianturi (Sianturi, S.R 1996), the provisions of Article 64 of the Criminal Code give rise to various opinions regarding the formula "there is such a relationship". The difference of opinion revolves around (1) whether the offense that occurs as a manifestation of only one wish must be the same or similar, (2) whether the offense is in the form of actions or has been in the form of an offense.

Debates related to the 3 (three) conditions for continuing actions are always interesting to learn. 
Table 1: Decisions on Corruption Cases That Are Conducted Continually

\begin{tabular}{|c|c|c|c|c|c|c|}
\hline Court & \multicolumn{5}{|c|}{$\begin{array}{l}\text { Case Handling } \\
2016 \text { to } 2020\end{array}$} & \multirow{2}{*}{$\begin{array}{c}\text { amount } \\
97\end{array}$} \\
\hline Jakarta Pusat & 29 & 23 & 10 & 15 & 20 & \\
\hline Bandung & 14 & 10 & 13 & 11 & 15 & 63 \\
\hline Surabaya & 17 & 7 & 3 & 5 & 9 & 41 \\
\hline Semarang & 27 & 3 & 14 & 10 & 7 & 61 \\
\hline \multicolumn{6}{|c|}{ amount } & 262 \\
\hline
\end{tabular}

Source: Directory of Decisions of the Supreme Court of the Republic of Indonesia, Information System for Case Tracing of the Supreme Court of the Republic of Indonesia, data accessed on 29 March 2019 - May 2021.

However, apart from the discussion on the three conditions, the legislators' intention regulates that the movement continues, namely relating to someone who has committed several criminal acts (both crimes and violations) on an ongoing basis.

Because continuing actions are seen as straftoemitingregel with a pure absorption system, of course, the position of Article 64 paragraph (1) of the Criminal Code is not taken into account. It will never fulfill the Indonesian people's expectations of severe penalties, ensnaring and impoverishing corruptors who recently increasingly surfaced even though this hope is always voiced by various groups of society, both by students, non-governmental organizations, the press, government, legislative institutions, even by political parties through their political jargons to eradicate corruption.

Expectations are like a hope that seems fantastic to be, but it isn't easy to realize. The public is even faced with the fact that there are corruptors who are subject to minimal penalties so that the corruptors can enjoy the results of their corruption in peace. This situation is, of course, inversely proportional to the 3 (three) characteristics given to corruption, namely (1) corruption as a transnational crime, (2) corruption as a great crime, and (3) corruption as a systemic and structured crime (Syarif, Laode M, et al. 2012).

Corruption crimes are also "white-collar crimes," that is, crimes that include a variety of nonviolent crimes usually committed in commercial situations for financial gain. Examples of white-collar crimes include fraud, embezzlement, forgery, and bribery (Prabowo, D 2019). Based on the data listed in the Case Tracing Information System of the Supreme Court of the Republic of Indonesia in several Courts, it shows that quite a several corruption cases between 2016 and 2018 were carried out continuously:
Based on the data in Table 1 above, 262 (two hundred and sixty two) corruption case decisions proven legally and convincingly carried out continuously, which were decided by 4 (four) corruption criminal courts. This number is, of course, quite a lot, and among the 262 decisions, there were 2 (two) decisions that captured the public's attention at the time the case was being held, among others:

1. Case on behalf of the defendant Otto Cornelis Kaligis Number: 89 / Pid.Sus/TPK/ 2015 / PN.Jkt.Pst sentenced the defendant to imprisonment for 5 (five) years and 6 (six) months, and a fine. in the amount of Rp. $300,000,000.00$ subsidiary imprisonment for 4 (four) months later in the Supreme Court decision number 1319K / PID.SUS / 2016 dated August 10, 2016, was declared legally and convincingly proven guilty of committing a criminal act of corruption as referred to the provisions of Article 6 paragraph (1) letter an of Law Number 31 of 1999 concerning Eradication of Corruption Crimes as amended by Law Number 20 of 2001 concerning Amendments to Law Number 31 of 1999 concerning Eradication of Corruption in conjunction with Article 55 paragraph (1) 1 of the Indonesian Criminal Code in conjunction with Article 64 paragraph (1) of the Indonesian Criminal Code and punishing the defendant therefore with imprisonment of 10 (ten) years and a fine of Rp. 500,000,000.00 (five hundred million rupiahs) provided that if the fine is not paid, the defendant will be subject to a penalty instead of a fine in the form of imprisonment for 6 (six) months.Let's look at the provisions of Article 6 of the Corruption Eradication Law. It states that imprisonment for a minimum of 3 (three) years and a maximum of 15 (fifteen) years and a fine of at least IDR $150,000,000.00$ (one hundred and fifty million 
rupiahs) and a maximum of Rp. $750,000,000.00$ (seven hundred and fifty million rupiah).

2. Corruption case on behalf of Patrialis Akbar, a former judge of the Constitutional Court of the Republic of Indonesia Number: 81 / PID.SUS / TPK / 2017 / PN.JKT.PST dated September 4, 2017. Patrialis Akbar has been proven to have committed a criminal act of corruption jointly and continued which as stipulated in Article 12 letter c in conjunction with Article 18 of the TPKjuncto Law Article 55 paragraph (1) and Article 64 paragraph (1) of the Criminal Code and sentenced the defendant Patrialis Akbar to 8 (eight) years in prison and a fine of Rp. 300,000. 000.00 a subsidiary of 3 (three) months in prison. The maximum punishment on the provision of Article 12 of the Corruption Eradication imprisonment of 20 years and a fine Rp.1.000.000.000, 00.

Based on the brief description of the case, the position of Voorgezette Handling should be of concern because when deciding that the defendant has been proven to have committed a criminal act of corruption continuingly, of course, it must have an impact on the sentence imposed. The weakness of the provisions of Voorgezette Handeling's position is seen as a criminal regulation that applies a pure absorption system, where only one criminal provision is applied which contains the heaviest basic criminal provisions so that it seems as if the heaviest criminal charges a lighter sentence. This situation can be said that the use of Article 64 of the Criminal Code in corruption cases is only a complement to the indictment or as an accessory to the indictment. In contrast, the consequence of the inclusion of an article in the indictment, the article elements of that article must be proven. If the details of the paper are fulfilled, it will result in legal consequences for the conviction given to the defendant. This does not apply to voorgezette handeling in corruption cases.

The fulfillment of the elements of Article 64 paragraph (1) Eradication of Corruption in the prosecutor's indictment has not been taken into account and does not give effect to punishment. As can be seen from the 170 (one hundred and seventy) decisions as referred to in Table 1 of the corruption case, which is Article 64 paragraph (1) of the Criminal Code so that there seems to be no difference when a corruption case is in conjunction with Article 64 of the Book of Law. Criminal without referring to the provisions of Article 64 of the Criminal Code.
The low number of crimes inflicted on the defendant is certainly not comparable to the consequences caused by the ongoing corruption committed by the defendant, especially with the classification of corruption crimes by Romli Atmasasmita as an extraordinary crime ( Rumokoy, NK 2011). Therefore, the conviction of corruption that is carried out continuously must of course, be of particular concern so that at a practical juridical level, for example in the case of Otto Cornelis Kaligis, the case of Ratu Atut Chosiyah and the case of Patrialis Akbar, the punishment imposed by the panel of judges on the defendant can apply a criminal threat. heavier, so that if it is related to Pompe's opinion which states his pessimism that Article 64 paragraph (1) of the Criminal Code should be abolished because fortunately it is not balanced with the practical difficulties it causes.

\section{Constraints to the Application of Article 64 of the Criminal Code in the Eradication of Corruption in Indonesia}

The Criminal Code recognizes 3 (three) types of combined criminal acts contained in title VI regarding combined criminal acts (Samenloop van Strafbare Feiten) (Fahrurrozi, F., and Salman Paris, AR 2019) :

\section{Eendadse samenloop \\ 2. Voorgezette handeling \\ 3. meerdaadse samenloop}

Samenloop van Strafbare Feiten consisting of eendadse samenloop (concursus idealist), voorgezette handeling (action ongoing) and meerdaadse samenloop (concursus realist), as mentioned above each have different characteristics and requirements of each other.

Samenloop van Strafbare Feiten is often connected with articles in the anti-corruption law. There were no dogmatic normative issues surfaced when the public prosecutor applied Article 64 paragraph (1) of the Criminal Code. According to Topo Santoso, reasonable in practice because of the difficulty of separating the acts of corruption as a single offense when committed by an official in their daily work through issues and projects alike. Furthermore, it is said that the one prosecutor Sriyanto, often gives the interpretation that this "one will decision" is an act of corruption itself. This clearly deviates from the example in Memorie Van Toelichtingm and the doctrine, which provides the interpretation that "a decision of the will" includes 
planning for the amount of money or goods that the perpetrator predetermines.

Topo Santoso also stated that the prosecutor, in analyzing the combined form of a criminal act as a continuing act (voorgezette handeling) seemed to equate a crime that was included in a tortured delict as exemplified in the provisions of Article 333 of the Criminal Code. The indication is that the prosecutor does not pay attention to the various examples that have been given both by Memorie Van Toelichting and by the doctrine regarding the meaning of the conditions in a combined criminal act as a continuing action, namely that several criminal acts must arise from one decision of the will (Aries, A. 2013).

In addition, interpreting voorgezette handeling is constrained by determining a material act (feit materieele) as a continuation act that cannot be equated with an act in the sense of a criminal act (offense) ; This situation is almost at the same time as the problem between the target of qualifying the type of crime between the criminal act of omission and the crime of commission (Aries , A 2013). Voorgezette handeling should not only be seen as a rule relating to the issue of criminal imposition and criminal weighting of a criminal act but must be placed in the part of proving the perpetrator's guilt. This can be understood when the voorgezette handeling determines the conditions, namely (1) there must be a decision of the will, (2) the action is for only one type of offense, and (3) the time interval between these actions is not too long. The issue of teaching deeds continues which continues to be a conversation among experts and continues on.

Voorgezette handeling is seen as criminal imposition rules (straftoemetingsregel), so Article 64 paragraph (1) of the Criminal Code is only a guideline for public prosecutors and judges to apply crimes against the principal offense, in this case, the criminal act of corruption.

The consequence of adhering to the teaching of continuing actions is closely related to the qualification of an act as a material act (materieele feit). Pompe argues that a material act is a physical act only, so it is only for commission offenses and should not be sought in any other form of crime. However, material action is not just a physical act but also a handling feitelijks. However, van Hamel reminded that feitelijkshandelingen should not be confused with eendaadsche sammeloopen or idealistic discourse.
Some of these acts are subject to criminal provisions resulting in different criminal acts between one action and the next.

The separate difficulty in continuing action was mentioned by Pompe, who once stated his pessimism that Article 64 paragraph (1) of the Criminal Code should be abolished because the benefits are not balanced with the practical difficulties it causes. The provisions of Article 64 of the Criminal Code give rise to various opinions regarding the formula "there is such a relationship" (Sianturi, SR 1996). The difference of opinion revolves around (1) whether the offense occurs as a manifestation of only one wish must be the same or the same thing, (2) whether it is in the form of actions or has been in the form of an offense.

The debate regarding the 3 (three) conditions in Voorgezette Handeling is always interesting to learn. However, apart from the discussion on the three conditions, the legislators' intention regulates the continuing action, namely relating to a person who commits several criminal acts (both crimes and violations), which are seen as one continuous act.

Because Voorgezette Handeling is only seen as a straftoemitingregel with a pure absorption system, it is not considered in its application. It will never fulfill the expectations of the Indonesian people of the presence of severe penalties, deterring and impoverishing corruptors who have recently become increasingly prominent even though this hope has always been voiced by various groups of society, both by students, non-governmental organizations, the press, government, legislative institutions, even by political parties through their political jargons to eradicate corruption.

Expectations are like a hope that seems fantastic to be, but it isn't easy to realize. The public is even faced with the fact that there are corruptors who are subject to minimal penalties so that the corruptors can enjoy the results of their corruption in peace.

\section{CONCLUSION}

Based on data in 2016, 2017, 2018, 2019, and 2020 case years, 262 corruption case decisions were carried out continuously and decided by four corrupt criminal courts. Obstacles in implementing Article 64 of the Criminal Code, namely (1) the difficulty of separating one corruption act as an offense single when it is carried out by an official who handles the same 
problems and projects daily, (2) often gives the interpretation that "one decision of the will" is an act of corruption itself in Memorie Van Toelichtingm or the doctrine that provides an interpretation that "a decision of the will" which includes planning for the amount of money or goods determined in advance by the perpetrator, (3) in interpreting the continuing action, it is constrained by determining the material act (feit materiel) as a continuation of action which cannot be equated with an act in the sense of a criminal act (offense), (4) Action should continue $t$ This is not only seen as a rule relating to the issue of imposing a sentence and the weighting of a criminal offense but it must be put in the section on proving the guilt of the perpetrator. Article 64 of the Criminal Code in connection with criminal acts of corruption in Indonesia should be of particular concern. It must have convictions if all elements are fulfilled so that it is not merely a complement to the prosecutor's indictment. Therefore, the provisions for continuing action should be seen as a rule relating to the issue of the imposition of a crime and the weighting of a criminal offense but must be put in the section on proving the perpetrator's guilt.

\section{REFERENCES}

Albert Aries, (2013). Penerapan Pasal 64 dan Pasal 65 ayat (1) KUHP (Gabungan Tindak Pidana) Retrieved May 6, 2021 (https://www.hukumonline.com/klinik/detail/ulasan/lt51af4a61 0defo/penerapan-pasal-64-dan-pasal-65-ayat-1-kuhpgabungan-tindak-pidana/)

Dalberg, J. (1907). Lord Acton (John Emerich Edward Dalberg) Letter to Archbishop Mandell Creighton (April 5, 1887). In N. Figgis, J \& V. Laurence, R (Eds.), Historical Essays and
Studies. London: Macmillan. Retrieved from https://history. hanover.edu/courses/excerpts/165acton.html

Direktori Putusan Mahkamah Agung Republik Indonesia, (2021) Retrieved May 6, $2021 \quad$ (https://putusan3. mahkamahagung.go.id/)

E. Utrecht. (2001). Hukum Pidana II,Kumpulan Bahan Kuliah.Surabaya: Tinta Mas,hlm. 14.

Furqan, AC, \& Din, M. (2019). Persepsi sosial tentang korupsi dan pengaruhnya terhadap legitimasi publik dan pemerintahan terbuka (Indonesia). Espacios, 40 (13).

Fahrurrozi, F., \& Salman Paris, AR (2019). Tinjauan Tentang Sistem Pemidanaan Dalam Perbarengan Tindak Pidana Menurut Kuhp. Media Keadilan: Jurnal IImu Hukum , 9 (2), 120. https://doi.org/10.31764/jmk.v9i2.889

Harlina, I. and Slamet Riyadi, B. (2020). Conflict of Law Enforcement by State Institutions over Abuse of Power and Authority: A Case Study of "Former President Director of PT. Pertamina", International Journal of Criminology and Sociology, 2020, 9, 2748-2756. https://doi.org/10.6000/1929-4409.2020.09.339

Klitgaard, Robert. (2005),Penuntun Pemberantasan Korupsi Dalam Pemerintahan Daerah, Yayasan Obor Indonesia, Jakarta, hlm.29

Lamintang, P.A.F, (1997). Dasar-Dasar Hukum Pidana Indonesia, Citra Aditya Bakti, Bandung, hlm. 34.

Lamintang, P.A.F (1984). Dasar-Dasar Hukum Pidana Indonesia.Bandung: Sinar Baru, hlm. 642.

Prabowo, Dedhy. (2019). Tinjauan Pengajuan Kasasi Penuntut Umum Terhadap Pembebasan Terdakwa Dari Dakwaan Primair Dalam Perkara Korupsi (Studi Putusan Mahkamah Agung Nomor: 134 K/Pid.Sus/2014), 2019. Verstek Volume 7 No. 1 Januari-April 2019

Rumokoy, NK (2011). Fungsi Hukum Pidana Internasional Dihubungkan Dengan Kejahatan Transnasional Khususnya Terhadap Tindak Pidana Korupsi. Jurnal Hukum Unsrat , 19 (4), 1-15. Diambil dari http://repo.unsrat.ac.id/47/1/18_Kelly_Rumokoy.pdf

Sianturi, S.R (1996).Asas-Asas Hukum Pidana di Indonesia dan Penerapannya, Jakarta: Alumni AHAEM-PETERHAEM, hlm. 338.

Syarif, Laode M dan Didik E. Purwoleksono, (2012). Hukum Ant Korupsi, Jakarta: The Asia Foundation, hlm.28-30.

Received on 14-05-2021

Accepted on 01-07-2021

Published on 09-07-2021

https://doi.org/10.6000/1929-4409.2021.10.138

(c) 2021 Kaplele et al.; Licensee Lifescience Global.

This is an open access article licensed under the terms of the Creative Commons Attribution Non-Commercial License (http://creativecommons.org/licenses/by-nc/3.0/) which permits unrestricted, non-commercial use, distribution and reproduction in any medium, provided the work is properly cited. 